\title{
Muscle-specific Overexpression of Lipoprotein Lipase Causes a Severe Myopathy Characterized by Proliferation of Mitochondria and Peroxisomes in Transgenic Mice
}

\author{
Sanja Levak-Frank, * Herbert Radner, ${ }^{\ddagger}$ Annemarie Walsh, ${ }^{5}$ Rudolf Stollberger," Gabriele Knipping, " Gerald Hoefler, ${ }^{\ddagger}$ \\ Wolfgang Sattler, * Peter H. Weinstock, Jan L. Breslow, ${ }^{\mathbf{5}}$ and Rudolf Zechner* \\ Institutes of * Medical Biochemistry and ${ }^{\ddagger}$ Pathology, Karl-Franzens University, 8010 Graz, Austria; ${ }^{8}$ Laboratory of Biochemical \\ Genetics and Metabolism, The Rockefeller University, New York, 10021; and "Gemeinsame Einrichtung Magnetresonanz, \\ Karl-Franzens University, 8010 Graz, Austria
}

\begin{abstract}
In extrahepatic tissues lipoprotein lipase (LPL) hydrolyzes triglycerides thereby generating FFA for tissue uptake and metabolism. To study the effects of increased FFA uptake in muscle tissue, transgenic mouse lines were generated with a human LPL minigene driven by the promoter of the muscle creatine kinase gene. In these mice human LPL was expressed in skeletal muscle and cardiac muscle, but not in other tissues. In proportion to the level of LPL overexpression, decreased plasma triglyceride levels, elevated FFA uptake by muscle tissue, weight loss, and premature death were observed in three independent transgenic mouse lines. The animals developed a severe myopathy characterized by muscle fiber degeneration, fiber atrophy, glycogen storage, and extensive proliferation of mitochondria and peroxisomes. This degree of proliferation suggests that FFA play an important role in the biogenesis of these organelles. Our experiments indicate that LPL is rate limiting for the supply of muscle tissue with triglyceride-derived FFA. Improper regulation of muscle LPL can lead to major pathological changes and may be important in the pathogenesis of some human myopathies. Muscle-specific LPL transgenic mouse lines will serve as a useful animal model for the investigation of myopathies and the biogenesis of mitochondria and peroxisomes. (J. Clin. Invest. 1995. 96:976-986.) Key words: lipoprotein lipase $\bullet$ free fatty acids $\bullet$ myopathy $\bullet$ mitochondria $\cdot$ peroxisomes
\end{abstract}

\section{Introduction}

In all vertebrates lipoprotein lipase (LPL) ${ }^{1}$ [E.C.3.1.1.34] is responsible for the hydrolysis of triglycerides from triglyceriderich lipoproteins (chylomicrons and VLDL) thereby supplying FFA for the subsequent uptake in extrahepatic tissues $(1,2)$.

Address correspondence to Rudolf Zechner, Institute of Medical Biochemistry, Karl Franzens University, Graz, Harrachgasse 21, 8010 Graz, Austria.

Received for publication 27 January 1995 and accepted in revised form 10 April 1995.

1. Abbreviations used in this paper: LPL, lipoprotein lipase; PAS, periodic acid-Schiff; PPAR, peroxisome proliferator-activated receptor

J. Clin. Invest.

(c) The American Society for Clinical Investigation, Inc.

0021-9738/95/08/0976/11 $\$ 2.00$

Volume 96, August 1995, 976-986
The human LPL gene is located on chromosome 8p22 (3). The major sites of LPL expression and enzymatic activity are muscle and adipose tissue. The enzyme is bound to the capillary endothelium probably by interaction with heparan sulfate. Hydrolysis of triglycerides by LPL is a prerequisite for the uptake of triglyceride-derived FFA by peripheral cells. Absence of the enzyme activity, as observed in patients affected with type I hyperlipoproteinemia, causes severe chylomicronemia and other metabolic complications (4-6). After uptake, the intracellular metabolism of FFA is quite different in various tissues. In muscle FFA are mainly utilized for $\beta$-oxidation and energy production. In adipose tissue FFA are reesterified and deposited as lipid droplets for storage. In accordance with these distinct metabolic functions, the regulation of extracellular triglyceride lipolysis by LPL is different in adipose tissue and muscle (7). For example, during fasting LPL activity is low in fat but high in muscle, whereas during refeeding it is high in fat but decreased in muscle. These tissue specific differences suggested a "gate keeping" function for LPL, which carefully balances the partitioning of triglyceride-derived FFA among different tissues (8).

Although the uptake mechanism of FFA into cells is still obscure, we speculated that tissue specific overexpression of LPL in muscle might represent an experimental model to increase FFA in myocytes. This would allow the investigation of the metabolic effects of FFA in muscle tissue. Therefore, human LPL was specifically overexpressed in skeletal muscle and heart muscle of transgenic mice and the physiological consequences of this overexpression were studied with regard to lipid metabolism as well as the intracellular effects of FFA. In addition to a decrease in the plasma triglyceride levels of transgenic mice, overexpression of human LPL in skeletal and cardiac muscle caused a remarkable increase in the number of mitochondria and peroxisomes in muscle fibers and the development of myopathy which resulted in the premature death in all transgenic animals. All these effects were correlated directly with the level of LPL expression in muscle tissue. We hypothesize that dysfunctional regulation of triglyceride hydrolysis and FFA uptake in muscle might be important in the pathogenesis of some human myopathies.

\section{Methods}

LPL-minigene construction. All cloning steps were performed according to well-established protocols (9). A human LPL expression construction was assembled from different partial LPL cDNA clones (10), a 1.3-kb fragment of the human gene containing $39 \mathrm{bp}$ of exon 3 , the complete intron 3 and 64 bp of exon 4. A 1093-bp DNA fragment containing $754 \mathrm{bp}$ of the last exon, the polyadenylation signal, and $339 \mathrm{bp}$ of gene flanking region was added to the 3 ' end. The LPL minigene was cloned into pBluescript. To isolate the regulatory sequences of the mouse cre- 
atine kinase gene (11), p3300MCKCAT (gift of Dr. R Hauschka, University of Washington, Seattle, WA) was cut with PstI and BstEII. These restriction cleavages yielded a DNA fragment of $3307 \mathrm{bp}$ of 5' flanking region. This fragment was subsequently cloned into $\mathrm{pBluescript}$ and fused with the LPL construction. The complete LPL-minigene, encompassing $8.5 \mathrm{~kb}$ of DNA, was prepared by cutting the plasmid with PstI and KpnI, isolating the linear DNA fragment by electroelution, and purifying it using a Elutip D column obtained from Schleicher \& Schuell, Inc. (Dassel, Germany).

Generation of transgenic mice. A linear piece of DNA encompassing the complete LPL minigene was injected into the male pronucleus of fertilized eggs from superovulated $(\mathrm{C} 57 \mathrm{~B} 1 / 6 \mathrm{~J} \times \mathrm{CBA} / \mathrm{J}) \mathrm{F} 1$ females that had been mated to males of the same genetic background (12). Microinjected eggs were transferred into the oviducts of surrogate females. Founder animals were bred to $(\mathrm{C} 57 \mathrm{Bl} / 6 \mathrm{~J} \times \mathrm{CBA} / \mathrm{J}) \mathrm{F} 1$ animals and three transgenic mouse lines were established: low expression line (MCK-L), medium expression line (MCK-M), and high expression line (MCK-H).

DNA and RNA analysis. For Southern blotting $10 \mu \mathrm{g}$ of tail tip DNA was digested with PvuII, fractionated by agarose gel electrophoresis, and blotted on nylon membranes. DNA corresponding to the human LPL minigene was detected with a radiolabeled 1.2-kb NcoI-EcoRI fragment from the human LPL cDNA. RNA isolation and blotting techniques were performed as described previously (13). To differentiate human LPL mRNA from the endogenous mouse mRNA a species-specific DNA-probe containing a 1-kb EcoRI fragment from exon 10 of the human LPL gene was used. This DNA probe specifically detected the 3 ' untranslated region of the human LPL mRNA but did not cross react with the mouse mRNA.

Lipolytic enzymes. Postheparin plasma was taken $5 \mathrm{~min}$ after bolus injection of sodium heparin $(100 \mathrm{U} / \mathrm{kg})$ into the tail vein. The epididymal fat pads and heart and thigh muscle specimens (100 mg each) were surgically removed from the animals and put into ice-cold tubes containing $1 \mathrm{ml}$ of DME medium with $2 \%$ BSA and $2 \mathrm{U} / \mathrm{ml}$ heparin. After mincing the tissue with scissors, it was incubated in medium for $1 \mathrm{~h}$ at $37^{\circ} \mathrm{C}$. Enzyme activities of LPL in muscle tissue and adipose tissue as well as LPL and hepatic triglyceride lipase activity in postheparin plasma of transgenic mice were assayed as described earlier (14). The assay of postheparin plasma was performed in the presence or absence of $1 \mathrm{M} \mathrm{NaCl}$ to estimate both the LPL and hepatic lipase activities. LPL activity was calculated as the portion of total lipase activity inhibited by $1 \mathrm{M} \mathrm{NaCl}$. To differentiate between human and mouse LPL activity in tissue extracts or postheparin plasma, the assay mixtures were preincubated for $1 \mathrm{~h}$ at $4^{\circ} \mathrm{C}$ in the presence of or absence of $0.1 \mu \mathrm{g} \mathrm{mAb} 5 \mathrm{D} 2$ (kindly provided by Dr. J. D. Brunzell, University of Washington, Seattle, WA) (15) or $10 \mu \mathrm{l}$ polyclonal antiserum prepared in our own laboratory (14). These antibodies both specifically inhibit the human but not the mouse enzyme in LPL activity determinations. After enzyme inhibition, activity measurements proceeded as described above.

Plasma parameters. Control and transgenic animals were fed a regular mouse chow ( $4.5 \%$ fat, $21 \%$ protein). Mice were housed in plastic cages and given free access to food and water. Blood was taken from etherized mice after an overnight fasting period and plasma was immediately prepared. Total plasma cholesterol was determined by the CHODPAP method (Greiner Diagnostica, Vienna, Austria). Triglycerides were determined using an enzymatic kit from Sero-Merieux (Vienna, Austria). FFA, glucose, and ketone bodies ( $\beta$-hydroxybutyrate) were measured enzymatically using kits obtained from Wako Chemicals (Neuss, Germany), E. Merck (Darmstadt, Germany) and Sigma Chemical Co. (St. Louis, MO), respectively. Plasma insulin was determined using a human radioimmunoassay kit obtained from Pharmacia LKB Biotechnology Inc. (Upsala, Sweden). The protocols provided by the manufacturers were followed.

FFA determinations in muscle tissue specimens. Steady state FFA concentrations in muscle tissue were determined by TLC/gas chromatography analysis of nonesterified fatty acid methyl esters. Skeletal muscle tissues of controls, MCK-L, MCK-M, and MCK-H were homoge- nized in liquid nitrogen and transferred to preweighed pyrex tubes and subsequently extracted in chloroform/methanol $(2: 1, \mathrm{vol} / \mathrm{vol})$, containing $0.2 \%$ acetic acid (16). The combined lipid extracts were dried under a stream of nitrogen and redissolved in $1 \mathrm{ml}$ of the same solvent system. 500- $\mu \mathrm{l}$ aliquots were transferred to teflon screw capped conical glass tubes, spiked with $50 \mu \mathrm{g}$ heptadecanoic acid as internal standard for gas chromatography analysis, dried under nitrogen, redissolved in $50 \mu \mathrm{l} \mathrm{CHCl}$ /methanol (2:1) containing $0.2 \%$ acetic acid and subjected to TLC separation on silica gel 60 alumina plates as described (17). During sample spotting a gentle stream of nitrogen was kept flowing over the lower half of the plate to avoid inadvertent oxidation of polyunsaturated fatty acids. The plates were developed in hexane/diethyl ether/ acetic acid (70:30:1, vol/vol) to separate nonesterified fatty acids from other tissue lipids. Lipid bands were visualized by a short exposure to iodine vapor. The band comigrating with the nonesterified fatty acid standards (linoleic and arachidonic acid) was scraped off and subjected to transesterification in $0.5 \mathrm{ml}$ toluene and $1 \mathrm{ml} \mathrm{BF} /$ /methanol $(20 \%$ $\left.\mathrm{BF}_{3}, 110^{\circ} \mathrm{C}, 90 \mathrm{~min}\right)(18)$. Fatty acid methyl esters were extracted in $250 \mu \mathrm{l}$ hexane and analyzed by gas-liquid chromatography on a HewlettPackard 5890 gas chromatography (equipped with an autoinjector, split/ splitless injector, flame ionization detector and a $25 \mathrm{~m} \times 0.32 \mathrm{~mm} \times 0.3$ $\mu$ m Hewlett-Packard $20 \mathrm{M}$ capillary column). Peaks were identified by comparison with the retention times of known standards. Quantitation was performed by peak area comparison with the internal standard (heptadecanoic acid).

Body weight and body composition. Total body weight of MCK-L, MCK-M, and MCK-H was measured weekly beginning $2 \mathrm{wk}$ after birth. The weight of the epididymal fat pad as a measure of white adipose tissue mass was determined from 12 to $14 \mathrm{wk}$ old mice. The average food intake was estimated by measuring the gram consumption of food weekly.

Magnetic resonance-analysis. For analysis by magnetic resonance imaging the animals were killed with Nembutal before scanning to avoid artifacts due to flow and movement. Imaging was performed at $1.5 \mathrm{~T}$ on a whole body system (ACS II; Philips Electronic Instruments Co., Mahwah, NJ) using a circular shaped receive coil with a diameter of $11 \mathrm{~cm}$. To reduce susceptibility artifacts due to tissue heterogeneities, a three-dimensional spin echo sequence with a repetition time of 100 $\mathrm{ms}$, an echo time of $26 \mathrm{~ms}$, and an excitation angle of $145^{\circ}$ was applied. For excitation the circular polarized body coil was used. The investigated volume consisted of 44 cross sections with a slice thickness of $1 \mathrm{~mm}$ and a field-of-view of $120 \times 60 \mathrm{~mm}$. The scanning matrix of $256 \times 128$ $\mathrm{mm}$ led to an in plane resolution of $0.47 \mathrm{~mm}$.

Microscopy and cytochemistry. Immediately after decapitation fresh muscle specimens from the upper and lower foreleg and hindleg were prepared for light microscopical, histochemical, and ultrastructural analyses. For electronmicroscopy samples of the skeletal muscles, nervus ischiadicus, and myocardium were fixed in $4 \%$ phosphate-buffered glutaraldehyde ( $\mathrm{pH} 7.2$ ) for $4 \mathrm{~h}$, postfixed with $1 \% \mathrm{OsO}_{4}$ in sodium cacodylate buffer, dehydrated, and finally embedded in Epon 812. After screening toluidine blue-stained semi-thin sections by light microscopy, ultrathin sections were cut with an OmU4 Ultracut ultramicrotome (Reichert Jung, Vienna, Austria), stained with uranyl acetate and lead citrate, and examined with an EM 400 electron microscope (Philips Electronic Instruments Co.) at $80 \mathrm{kV}$. For histochemical investigations unfixed muscle specimens were frozen in 5-methylbutan (E. Merck) which was precooled in liquid nitrogen, and stored at $-20^{\circ} \mathrm{C}$ until 4$\mu \mathrm{m}$ cryocut sections were stained with haematoxylin and eosin, myosin adenosine triphosphatase (ATPase after preincubation at $\mathrm{pH} 4.2,4.6$, and 9.4 for classifying fiber types), NADH tetrazolium reductase (NADH-TR, staining mitochondria, but also interfibrillary sarcoplasmatic tubules and reticulum), Gomori-trichrome (mitochondrial stain), and oil red-O (lipid staining) techniques. In addition to formalin-fixed (neutral phosphate-buffered 10\% formaldehyde solution) specimens of the muscles and samples from other organs (e.g., the whole brain in frontal slices, the whole heart in transverse sections, lungs, liver, gastrointestinal tract, spleen, kidney, adrenal gland, and urogenital tract) were embedded in paraffin wax by conventional techniques and investigated 
in haematoxylin and eosin-, Masson-trichrome, and periodic acid Schiff (PAS)-stained sections. Cytochemical staining for intracellular catalase activity using diaminobenzidine for the visualization of peroxisomes was performed as described by Roels et al. (19). The enzymatic activity of the mitochondrial marker enzyme succinate dehydrogenase was performed according to Peters et al. (20). Catalase activity, as a marker for peroxisomes was measured as described by Pennington (21).

\section{Results}

Generation of transgenic mice. An LPL minigene was constructed containing the full-length human LPL cDNA (10) including the 5' untranslated sequence, the complete coding region, the 3' untranslated sequence, and 339 bp of 3 ' flanking region (Fig. $1 A$ ). The coding region of this construction was interrupted by a single intron (intron 3 of the human LPL gene) as the presence of at least one intron has been demonstrated to increase the level of expression of transgenes (22). The complete minigene was fused with a 3.3-kb piece of DNA containing the promoter region of the mouse muscle creatine kinase gene (kindly provided by Dr. S. D. Hauschka, University of Washington, Seattle, WA). This promoter has been successfully used in the highly tissue-specific overexpression of a reporter gene in skeletal muscle and heart muscle of transgenic mice (11). LPL-transgenic mice were generated as previously described (8). Three transgenic mice were obtained as founders resulting in three independent lines (MCK-L, MCK-M, and MCK-H).

Transgene integration and expression. Semiquantitative Southern blotting (Fig. 1 B) revealed that MCK-L had three copies of the LPL minigene integrated in its genome. MCK-M contained 10 copies and MCK-H integrated an estimated number of 20 copies per genome. LPL gene expression was measured by mRNA and enzyme activity levels. Using a speciesspecific probe, human LPL mRNA of the expected size (3.6 kb) was found in skeletal muscle and cardiac muscle of mice from all transgenic lines (Fig. $1 C$ ). The least amount of this transcript was detected in MCK-L, followed by MCK-M. MCK$\mathrm{H}$ expressed the highest amount of human LPL-mRNA in muscle tissue. No human LPL mRNA was detected in adipose tissue or any other tissue except muscle, verifying the highly tissuespecific properties of the muscle creatine kinase promoter. As expected, no human LPL mRNA signal was detected in nontransgenic control mice indicating the specificity of the DNA probe.

The enzyme activities of endogenous mouse LPL and human LPL were analyzed in skeletal muscle, heart, and adipose tissue in all transgenic mouse lines as well as control mice (Table I). Heparin releasable LPL activity in skeletal muscle exhibited a highly significant 5.5 -fold increase of LPL activity in MCK-L, an 8.1-fold increase in MCK-M, and a 24.4-fold increase in MCK-H animals compared to the levels in control mice. A similar result, although less pronounced was obtained for heparin-releasable LPL activities in cardiac muscle, which was found to be increased by $20 \%$ in MCK-L, $55 \%$ in MCK$M$ and $221 \%$ in MCK-H over the endogenous mouse LPL activity. To differentiate the human from mouse LPL activity, a polyclonal antiserum or the monoclonal antibody 5D2 (a gift of Dr. J. Brunzell, University of Washington, Seattle, WA) directed against human LPL was used for the specific inhibition of the human enzyme $(14,15)$. These antibodies do not inhibit mouse LPL. Inhibition experiments revealed that the additional LPL activity found in muscle tissue of transgenic animals was
A

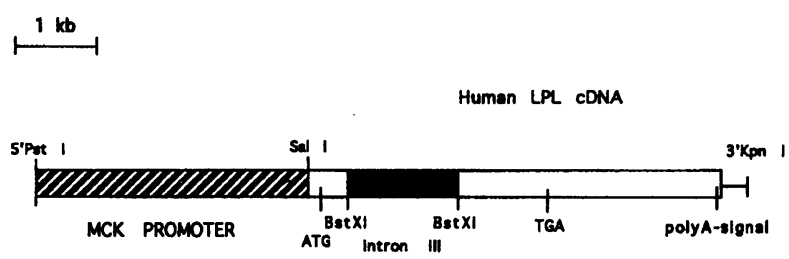

B DNA

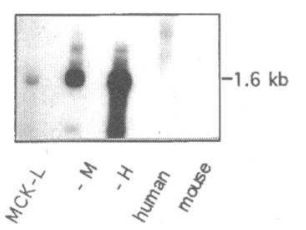

C RNA
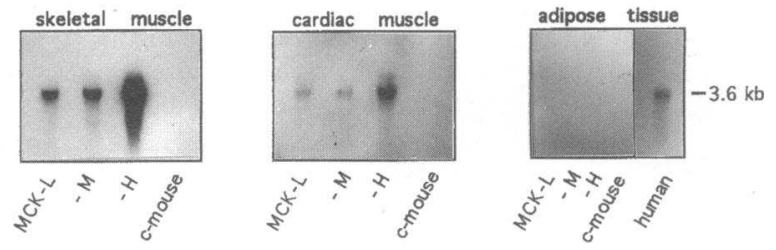

Figure 1. (A) The LPL-minigene DNA construction used for microinjection. The minigene was assembled from a human LPL cDNA (open box), the human LPL gene (filled box), and the promoter sequences of the mouse creatine kinase gene (hatched box) by conventional cloning techniques. The translational start codon ( $A T G)$, stop codon (TGA), and the polyadenylation signal (poly A-signal) of the LPL minigene are indicated. $(B)$ DNA analysis. Integration of the human LPL minigene in three transgenic mouse lines stemming from three independent founder mice. The presence and the amount of integrated copies of the minigene into the genome of the mouse was determined by Southern blotting analysis of $10 \mu \mathrm{g}$ of tail tip DNA. The presence of a $1.6-\mathrm{kb}$ band (labeled on the right) indicated the integration of the LPL minigene. The highest copy number was detected in MCK-H animals (20 copies) followed by MCK-M ( 10 copies), and MCK-L animals (3 copies). Nontransgenic mice (mouse) as well as human control DNA ( human) provided no specific signal of the appropriate size. $(C)$ mRNA analysis. Expression of human LPL mRNA was measured in skeletal muscle, heart muscle, and adipose tissue of three transgenic mouse lines and control animals by Northern blotting analyses. To differentiate human LPL mRNA from the endogenous mouse mRNA a species specific DNA-probe containing a 1-kb EcoRI fragment from exon 10 of the human LPL gene was utilized. This DNA probe specifically detected the $3^{\prime}$ untranslated region of the human LPL mRNA but did not crossreact with the mouse LPL mRNA. Human LPL mRNA was detected in skeletal muscle and heart muscle but not in adipose tissue of all transgenic mouse lines ( $M C K-L, M C K-M$, and $M C K-H)$. LPL mRNA size was similar to human adipose tissue LPL mRNA (human). No specific signal was observed in muscle or adipose tissue of control mice (c-mouse).

completely attributable to the expression of human LPL. In adipose tissue no human LPL activity was detected in addition to the endogenous mouse LPL activity. Expression of human LPL in transgenic mice did not influence the endogenous mouse 
Table I. Enzyme Activities of LPL and HL in Tissues and Postheparin Plasma of Transgenic Mouse Lines and Control Mice

\begin{tabular}{lccccccc}
\hline \multicolumn{9}{c}{ Lipolytic enzymes } \\
\hline & & \multicolumn{2}{c}{ LPL activity in tissue $(\mu$ M FFA/gram per $\mathrm{h}) n=15$} & & \multicolumn{2}{c}{$\begin{array}{c}\text { Lipolytic activity in plasma } \\
(\mu \mathrm{M} \text { FFA/ml per } \mathrm{h}) n=6\end{array}$} \\
\cline { 3 - 8 } & Copy number & Skeletal muscle & Cardiac muscle & Adipose tissue & & LPL & HL \\
\hline Controls & - & $1.48 \pm 0.53$ & $8.35 \pm 1.93$ & $1.28 \pm 0.45$ & & $15.55 \pm 3.70$ & $6.20 \pm 1.58$ \\
MCK-L & 3 & $8.20 \pm 1.10^{*}$ & $10.05 \pm 1.05$ & $0.93 \pm 0.55$ & & $23.28 \pm 5.43^{\S}$ & $4.33 \pm 2.08$ \\
MCK-M & 10 & $11.98 \pm 1.58^{*}$ & $12.95 \pm 2.40^{\S}$ & $1.60 \pm 0.33$ & & $29.10 \pm 3.80^{\S}$ & $5.68 \pm 1.13$ \\
MCK-H & 20 & $36.08 \pm 6.30^{*}$ & $26.80 \pm 9.08^{*}$ & $2.15 \pm 0.90$ & & $34.30 \pm 2.25^{\ddagger}$ & $4.73 \pm 1.38$ \\
& & & & & & & \\
\hline
\end{tabular}

${ }^{*} P<0.0001 ;{ }^{\ddagger} P<0.001 ;{ }^{8} P<0.01$. All values represent means \pm SD. Age of animals at the time of analysis: $8-12 \mathrm{wk}$.

LPL activity, since inhibition of human LPL in tissue extracts of transgenic mice resulted in comparable enzyme activities as found in control mice. As a consequence of the expression of human LPL in muscle tissue, human LPL activity was also detectable in mouse post heparin plasma (Table I). A gene dose-dependent increase was found in the transgenic lines in good agreement with the results obtained for LPL activities in muscle tissue. The activity of hepatic triglyceride lipase in the postheparin plasma of transgenic mice was not affected by the expression of human LPL.

Metabolic effects of LPL overexpression in muscle. Table II summarizes the results obtained from the analyses of lipids and plasma parameters in the transgenic lines and control mice. All mice had access to standard laboratory chow (4.5\% fat, $21 \%$ protein) and were fasted overnight before blood drawing. Plasma triglyceride levels were lowered in proportion to the level of LPL expression (44.2\% in MCK-L, $56.5 \%$ in MCK$\mathrm{M}$, and $61.1 \%$ in MCK-H at $2-3$ mo of age) in transgenic animals compared to controls. Low plasma triglyceride levels were observed over the life span of the animals and was due to a decrease in plasma VLDL. Plasma cholesterol was not significantly different in transgenic mice versus control mice.

Fasting glucose and insulin levels were not significantly different in transgenic compared to control mice, indicating normal glucose metabolism (Table II). Increased lipolysis in skeletal and heart muscle did not cause increased FFA levels in the plasma of transgenic animals. Additionally, liver-derived ketone bodies ( $\beta$-hydroxybutyrate) was also indistinguishable between transgenic and control animals (Table II). This suggested that the majority of FFA was directly taken up by muscle tissue without entering the plasma pool. To demonstrate postlipolytic uptake of FFA in muscle tissue, steady state FFA concentrations were measured as fatty acid methyl ester derivatives in tissue specimens of the thigh muscles of transgenic and control animals (Table II). Compared to control animals, steady state FFA concentrations were unchanged in muscle tissue of MCK-L, but increased in MCK-M animals (2.6-fold) and MCK-H animals (4.3-fold).

Effects on body weight and body composition. The increased flux of FFA into skeletal muscle tissue through LPL overexpression had a pronounced effect on body weight and body composition in transgenic animals. Fig. 2 displays the time course of body weight gain over the first 3 mo of life for all transgenic lines. LPL-transgenic mice exhibited reduced body weight depending on the level of LPL expression in muscle tissue. Animals with higher LPL expression gained less weight than animals with lower LPL expression. The lowest expressing line MCK-L did not exhibit slow weight gain during the initial 12 wk after birth. However, between 12 and 18 mo of age these animals lost weight and died prematurely. MCK-M, the medium expressing line, gained weight slower than control mice. After 8 wk of age the animals reached only $90 \%$ of the weight of control animals and, in contrast to control mice, did not gain any further weight. At 10 to 12 wk of age, the animals started

Table II. Summary of Biochemical Data from Plasma and Muscle Tissues of Three Transgenic Mouse Lines and Control Mice

\begin{tabular}{|c|c|c|c|c|c|c|c|}
\hline & \multicolumn{6}{|c|}{ Serum analysis } & \multirow{2}{*}{$\frac{\text { Skeletal muscle }}{\text { FFA }}$} \\
\hline & Triglycerides & Cholesterol & Glucose & Insulin & Ketone bodies & FFA & \\
\hline & $m g / d l$ & $m g / d l$ & mM/iter & pm/iter & mM/iter & mM/iter & $\mathrm{mg} / \mathrm{mg}$ wet tissue \\
\hline Controls & $\begin{array}{c}79.9 \pm 17.3 \\
n=20\end{array}$ & $\begin{array}{c}63.8 \pm 10.5 \\
n=20\end{array}$ & $\begin{array}{c}4.75 \pm 1.0 \\
n=20\end{array}$ & $\begin{array}{c}18.1 \pm 8.6 \\
n=6\end{array}$ & $\begin{array}{c}1.38 \pm 0.60 \\
n=6\end{array}$ & $\begin{array}{c}1.11 \pm 0.21 \\
n=16\end{array}$ & $\begin{array}{c}0.16 \pm 0.05 \\
n=7\end{array}$ \\
\hline MCK-L & $\begin{array}{c}44.6 \pm 13.8^{*} \\
n=20\end{array}$ & $\begin{array}{c}64.2 \pm 10.2 \\
n=20\end{array}$ & $\begin{array}{c}4.60 \pm 0.82 \\
n=15\end{array}$ & $\begin{array}{c}25.7 \pm 7.9 \\
n=6\end{array}$ & $\begin{array}{c}1.04 \pm 0.23 \\
n=6\end{array}$ & $\begin{array}{c}1.44 \pm 0.29^{\ddagger} \\
n=14\end{array}$ & $\begin{array}{c}0.20 \pm 0.08 \\
n=4\end{array}$ \\
\hline MCK-M & $\begin{array}{c}34.8 \pm 3.9^{*} \\
n=20\end{array}$ & $\begin{array}{c}61.3 \pm 15.7 \\
n=20\end{array}$ & $\begin{array}{c}4.77 \pm 1.32 \\
n=19\end{array}$ & $\begin{array}{c}19.3 \pm 5.7 \\
n=6\end{array}$ & $\begin{array}{c}1.41 \pm 0.53 \\
n=7\end{array}$ & $\begin{array}{c}0.78 \pm 0.15^{\ddagger} \\
n=11\end{array}$ & $\begin{array}{c}0.41 \pm 0.26 \\
n=4\end{array}$ \\
\hline MCK-H & $\begin{array}{c}31.1 \pm 2.9 * \\
n=20\end{array}$ & $\begin{array}{c}52.9 \pm 7.9 \\
n=20\end{array}$ & $\begin{array}{c}4.13 \pm 0.86 \\
n=7\end{array}$ & $\begin{array}{c}15.7 \pm 8.6 \\
n=3\end{array}$ & $\begin{array}{c}1.58 \pm 0.82 \\
n=4\end{array}$ & $\begin{array}{c}1.25 \pm 0.21 \\
n=7\end{array}$ & $\begin{array}{c}0.70 \pm 0.21^{\ddagger} \\
n=5\end{array}$ \\
\hline
\end{tabular}

${ }^{*} P<0.0001 ;{ }^{\ddagger} P<0.01$; All values represent means \pm SD. Age of animals at the time of analysis: $8-12 \mathrm{wk}$. 


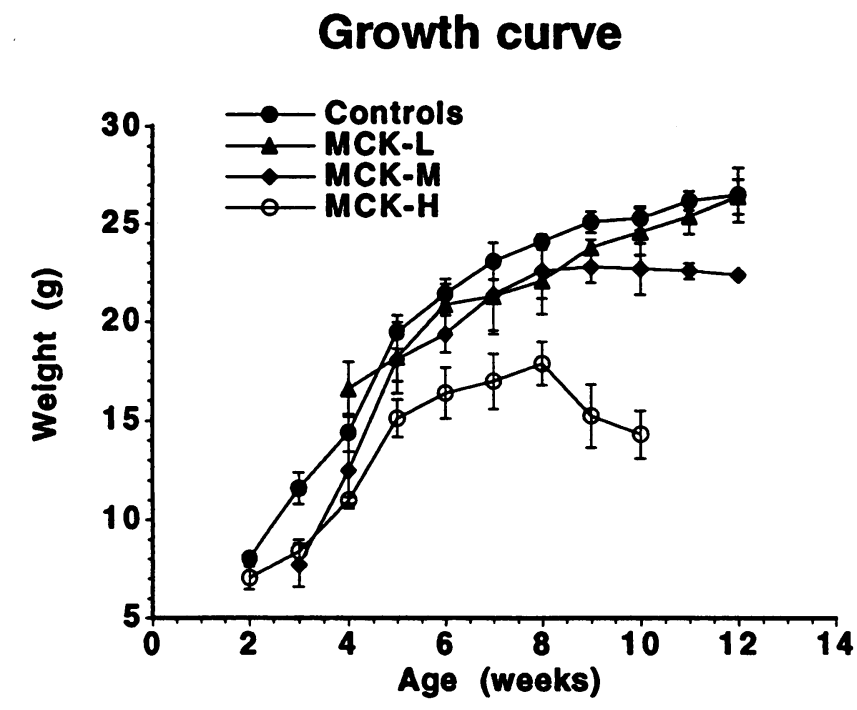

Figure 2. Growth curves of three transgenic mouse lines ( $M C K-L, M C K$ $M$, and $M C K-H$ ) compared to control mice. Total body weight (grams) of 20 animals of each group (MCK-L, MCK-M, and MCK-H) was determined every $7 \mathrm{~d}$ beginning $2 \mathrm{wk}$ after birth for a time course of $12 \mathrm{wk}$. Values are presented as means \pm SD.

slowly to lose weight and died prematurely at the age of 8-12 mo. In MCK-H, the highest expressing line, the growth curve was most obviously changed compared to control mice. During the first 2 mo after birth these animals gained only $75 \%$ of the weight of control mice. After this time point MCK-H animals started to lose weight rapidly. 10 wk after birth they attained only $43 \%$ of the body weight of age matched control mice. This wasting process resulted in death of the animals between 10 and 12 weeks after birth. The observed weight loss in transgenic animals was probably not due to decreased food intake, since food consumption per body weight was similar in all lines over a period of $3 \mathrm{wk}$ (not shown).

To analyze body composition with regard to muscle versus adipose tissue mass, transgenic and control mice were subjected to representative $\mathrm{T} 1$-weighted magnetic resonance image analyses (23). Fig. 3 exhibits a longitudinal section of a 5-mo-old control animal, a 5-mo-old MCK-M animal, and an 8-wk-old MCK-H animal. MCK-L animals at 5 mo of age were phenotypically normal. In MCK-M animals a moderate loss of muscle tissue as well as adipose tissue was observed (Fig. 3). 2-moold MCK-H animals exhibited a massive loss of muscle mass as well as the virtually complete disappearance of adipose tissue (Fig. 3), which accounted for the overall weight loss in these animals. The loss of adipose tissue was also confirmed by macroscopic pathological examination of five animals which showed that the epididymal fat pads were scarcely detectable.

Effects on muscle morphology. The "lipolysis induced" loss of muscle mass in transgenic mice was morphologically investigated by light microscopy, histochemical procedures, and electron microscopy of skeletal and heart muscle tissue in two male and two female animals of each line $8 \mathrm{wk}$ after birth. Since the MCK-L and MCK-M animals did not show any pathologic changes within $8 \mathrm{wk}$, animals were also examined 5 mo post partum.

Light microscopically (Fig. 4), skeletal muscle samples

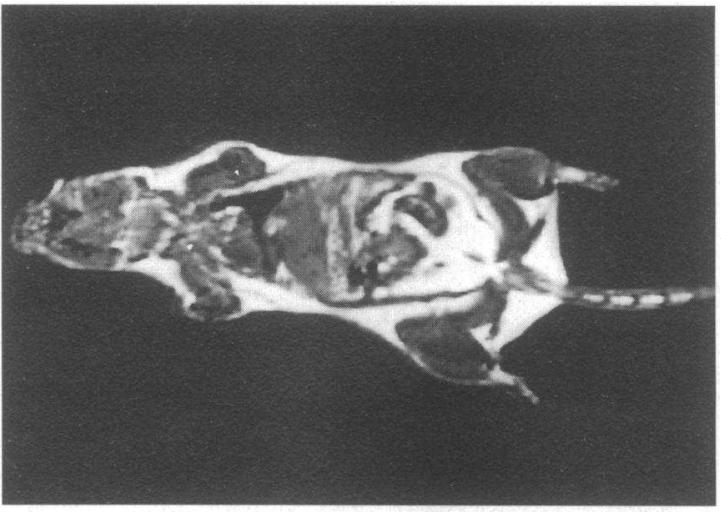

B

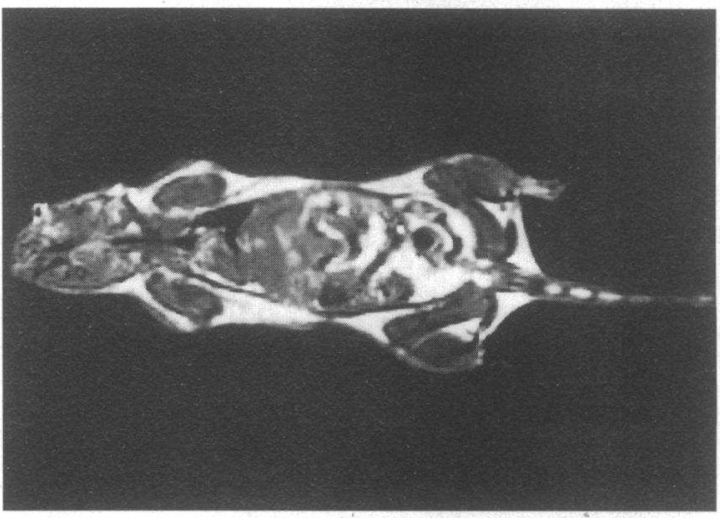

C

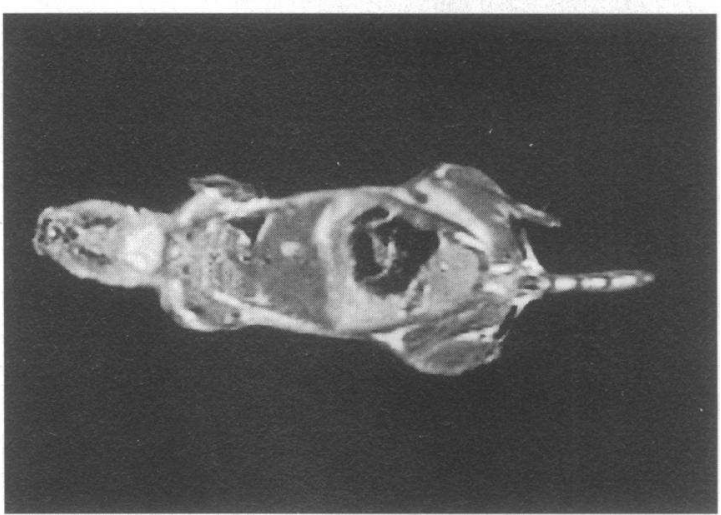

Figure 3. Nuclear magnetic resonance analyses of control and transgenic animals. Representative T1-weight MR-images from control animals $(A)$, MCK-M $(B)$, and MCK-H $(C)$. Within these T1-weighted spin echo images the adipose tissue appears bright in contrast to remaining tissues. Out of 44 cross sections with a thickness of $1 \mathrm{~mm}$ a single section is displayed. Field of view: $120 \times 60 \mathrm{~mm}$.

from 5-mo-old MCK-L animals were found to be identical compared to control animals ( $a$ and $d$ ). Similarly, samples from MCK-M animals exhibited no obvious myopathic changes at this age ( $b$ and $e$ ). In PAS-stained sections only a few fibers exhibited a low degree of glycogen storage in subsarcolemmic position. In contrast, in MCK-H animals a severe myopathy with fiber degeneration, fiber atrophy, lymphocytic, and mesenchymal reaction was already detectable within 2 mo of age ( $c$ and $f$ ). Large amounts of PAS-positive material was found suggesting massive glycogen storage $(c)$. No positive reaction was obtained in histochemical staining with oil red-O indicating the absence of neutral lipid accumulation. Additionally, MCK- 

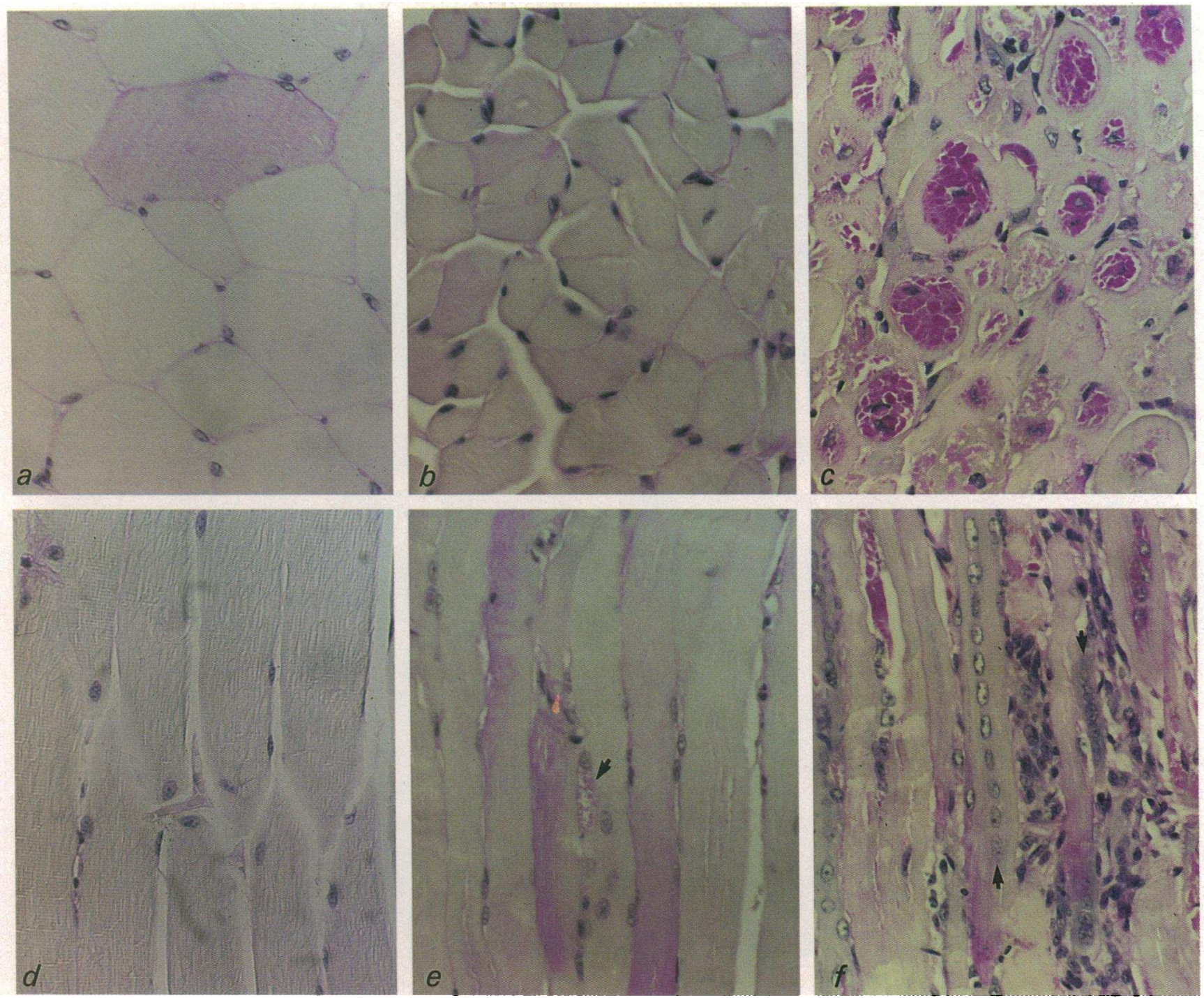

Figure 4. Light microscopy of skeletal muscle specimens. Morphological examination by light microscopy of periodic acid Schiff (PAS) -stained transverse $(a, b$, and $c)$ and longitudinal $(d, e$, and $f)$ sections of skeletal muscle specimens from control animals (5 mo of age) and LPL-transgenic mice, MCK-M ( 5 mo of age), and MCK-H ( 2 mo of age). Compared to control animals ( $a$ and $d$ ) MCK-M mostly presented normal skeletal muscles $(b$ and $e)$ at 5 mo of age. In only a few muscle fibers local glycogen storage was detected $(e$, arrow). In contrast, even at 2 mo of age severe myopathy was found in the MCK-H animals $(c$ and $f$ ). This myopathy was characterized by excessive glycogen storage in muscle fibers (stained intensively red by PAS reaction in $c$ and $f$ ), muscle fiber degeneration, atrophy, lymphocytic, and mesenchymal reaction. Additionally, many centralized nuclei forming nuclear chains $(f$, arrows), which resemble myotubes, were detected in longitudinal sections of muscle fibers. $a$, $b, c \times 1650$ (original negative $\times 440$ and $d, e, f \times 1,125$ (original negative $\times 300$ ).

H samples exhibited an increased number of nuclei in a central position resembling myotubes $(f)$.

Electronmicroscopically (Fig. 5), skeletal muscle samples from MCK-L animals were morphologically identical to control animals $(a$ and $d)$ at 5 mo of age. In contrast, MCK-M samples at this stage exhibited a most obvious increase in the number of mitochondria in the subsarcolemmic, perinuclear, and intermyofibrillar position of muscle fibers ( $b$ and $e$ ). Only very moderately increased glycogen deposition was found in vesicles or diffusely dispersed in the sarcoplasma of MCK-M samples. In skeletal muscle specimens of MCK-H animals the number of vital mitochondria was only moderately increased, but many residual mitochondria which had undergone cystic degenerative changes were detected between membranous degenerative ma- terial ( $c$ and $f$ ). In contrast to MCK-M, massive glycogen storage was observed in MCK-H samples in the sarcoplasma. These granules were partly dispersed between myofibrills and partly surrounded by membranes. Glycogen deposits were also detected in nuclear inclusions which were surrounded by invaginations of nuclear membranes $(c)$. In summary these morphological studies show that the onset and degree of myopathic changes in skeletal muscle tissue was strongly correlated to the degree of LPL overexpression in all transgenic lines.

Cross sections of the heart were also investigated by light and electron microscopy. In MCK-M, and to a higher degree in MCK-H, an increased number of mitochondria was found in myocytes. However, only slight to moderate myopathic changes could be observed (not shown). LPL overexpression in 

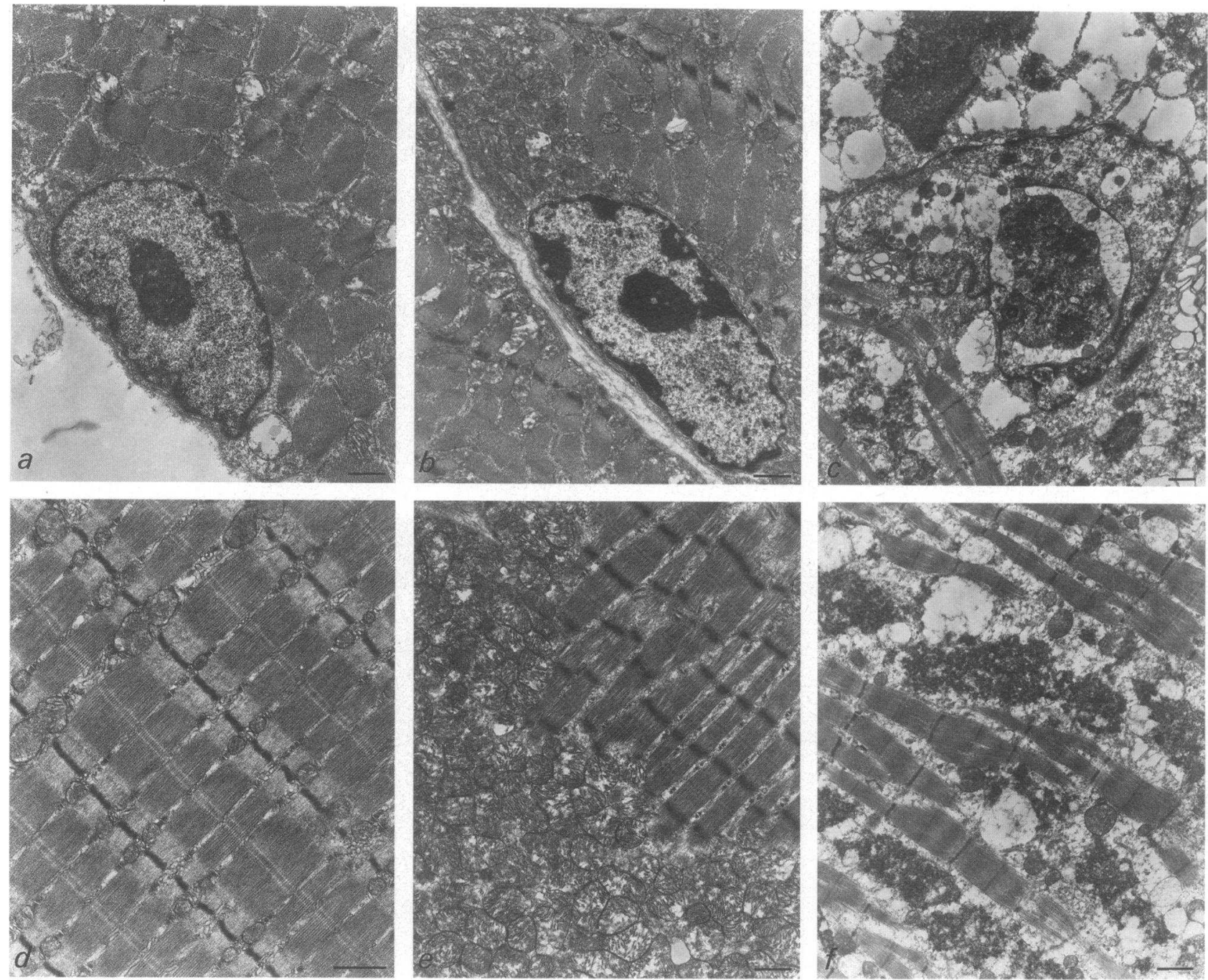

Figure 5. Electron microscopy of skeletal muscle specimens. Electronmicroscopical analysis of skeletal muscle specimens from control animals (5 mo of age) and LPL-transgenic mice, MCK-M ( 5 mo of age), and MCK-H ( 2 mo of age). Compared to controls ( $a$ and $d$ ), increased numbers of mitochondria were detected in subsarcolemmic perinuclear $(b)$ and intermyofibrillar $(e)$ positions in MCK-M. Severe myopathy was found in MCK-H, characterized by excessive perinuclear $(c)$ and intermyofibrillar $(f)$ glycogen storage with nuclear invagination $(c)$ and degeneration of myofibrills $(f)$. Uranyl acetate and lead citrate. Bars represent $1 \mu \mathrm{m}$.

transgenic mice had no effect on the morphology of all other organs analyzed including liver, spleen, kidney, adrenal glands, brain, lungs, and gastrointestinal as well as urogenital tracts.

Effects on the biogenesis of mitochondria and peroxisomes. As described in the preceeding section, increased LPL expression in skeletal muscle caused a drastic increase in the number of mitochondria in muscle cells of MCK-M animals. This increase was detected by electron microscopy, but also in toluidine blue-stained semithin sections and by histochemistry with NADH-tetrazolium-reductase and Gomori trichrome stainings $(24,25)$. As judged from morphologic examinations, a five- to eightfold increase in the number of mitochondria was estimated in MCK-M animals compared to control animals. This morphologic finding was also confirmed by biochemical analyses of succinate dehydrogenase activity, a marker enzyme of mitochondria, which was found to be increased two- to threefold in skeletal muscle samples of MCK-M mice (Table III). The degree of mitochondrial proliferation was consistently more pronounced in morphological examinations compared to the en- zyme assay. As judged from electron microscopy, the number of mitochondria in muscle samples from MCK-H animals, the line with highest LPL expression, was found to be only slightly increased compared to control animals, but much lower than in skeletal muscle of MCK-M animals. This difference was not found in the activity of the mitochondrial marker enzyme succinate dehydrogenase, which was identical in muscle specimens from MCK-M and MCK-H animals (Table III).

The effects of muscle-specific overexpression of LPL on peroxisome proliferation was investigated by electron microscopy and by determining the activity of catalase, a peroxisomal marker enzyme. The number of peroxisomes was extremely low in skeletal muscle specimens of control animals. There were only one or fewer peroxisomes per microscopic field (Fig. $6 A)$. In contrast, specimens from MCK-M $(b)$ animals and MCK-H $(c)$ animals had between four and six peroxisomes per microscopic field, indicating a striking increase in the number of peroxisomes (Fig. $6 b$ and $c$ ). Catalase activity was increased fourfold in skeletal muscle of MCK-L animals and eightfold in 
Table III. Summary of Morphological Analyses of Muscle Tissue and Biochemical Assays of Mitochondrial and Peroxisomal Marker Enzymes in Muscle Specimens of Transgenic Mouse Lines and Control Mice

\begin{tabular}{|c|c|c|c|c|c|c|}
\hline & Light microscopy & Mitochondriopathy & $\begin{array}{l}\text { SDH activity } \\
\text { [mU/mg protein] }\end{array}$ & Peroxisomes & $\begin{array}{l}\text { Catalase activity } \\
\text { [mU/mg protein] }\end{array}$ & $\begin{array}{c}\text { Glycogen } \\
\text { storage }\end{array}$ \\
\hline Controls & Normal & Normal & 5.0 & Normal & 1.8 & Normal \\
\hline MCK-L (5 mo)* & Normal & Normal & 5.4 & $\ddagger$ & 7.4 & Normal \\
\hline MCK-M (5 mo)* & Minimal changes & 8 & 11.4 & 8 & 14.1 & $\ddagger$ \\
\hline MCK-H (2 mo)* & $\begin{array}{l}\text { Severe myopathy } \\
\text { Fiber degeneration } \\
\text { Central nuclei }\end{array}$ & $\ddagger$ & 11.3 & 8 & 13.6 & 8 \\
\hline
\end{tabular}

${ }^{*}$ Age of animals at the time of analysis; ${ }^{\ddagger}$ moderately increased; ${ }^{8}$ strongly increased; SDH, succinate-dehydrogenase; enzyme activities represent the means of two independent experiments.

both MCK-M and MCK-H animals, confirming the morphological results (Table III). The observation that catalase activity was similar in MCK-M and MCK-H animals, suggests that there is some upper limit to the peroxisome induction by muscle LPL expression. Catalase activity in the liver of transgenic animals was not increased compared to normal mouse liver indicating that the increase in peroxisomes was muscle specific (not shown).

\section{Discussion}

Overexpression of human LPL in skeletal and cardiac muscle of transgenic mice resulted in major alterations of the lipid and energy metabolism of the animals. The increase in lipolytic activity was much more pronounced in skeletal muscle than in heart muscle. Increased lipolysis by LPL resulted in increased intracellular FFA levels. This was associated with weight loss and premature death. The animals developed a severe myopathy characterized by the proliferation of mitochondria and peroxisomes, glycogen storage, lymphocyte infiltration, fiber atrophy, fiber degeneration, and centralized nuclei. These various find- ings were solely dependent on the level and duration of LPL overexpression in muscle tissue.

In the plasma compartment increased LPL activity in muscle caused a dose-dependent reduction of the triglyceride concentrations, which was mainly due to a reduction of VLDL. Unexpectedly, the plasma concentration of FFA were not increased with increased LPL activity in transgenic mice. Low plasma FFA concentrations and, presumably, FFA transport rates to the liver were also reflected by the unchanged plasma ketone body concentrations in transgenic animals. This suggests that the majority of FFA are directly taken up by muscle tissue without entering the plasma pool. In fact, intracellular FFA concentrations were found to be increased in skeletal muscle tissue of transgenic mice in proportion to the level of LPL overexpression. It has been suggested that the cellular uptake of FFA is facilitated by two types of mechanisms, lateral movement of FFA over the cell membrane followed by the direct cellular uptake $(26)$, or specific FFA transport protein-mediated uptake $(27,28)$. Several candidate proteins have been identified from different tissues in the past including a $40-\mathrm{kD}$ protein and the fatty acid transporter protein (29-32). To date, however, characterization
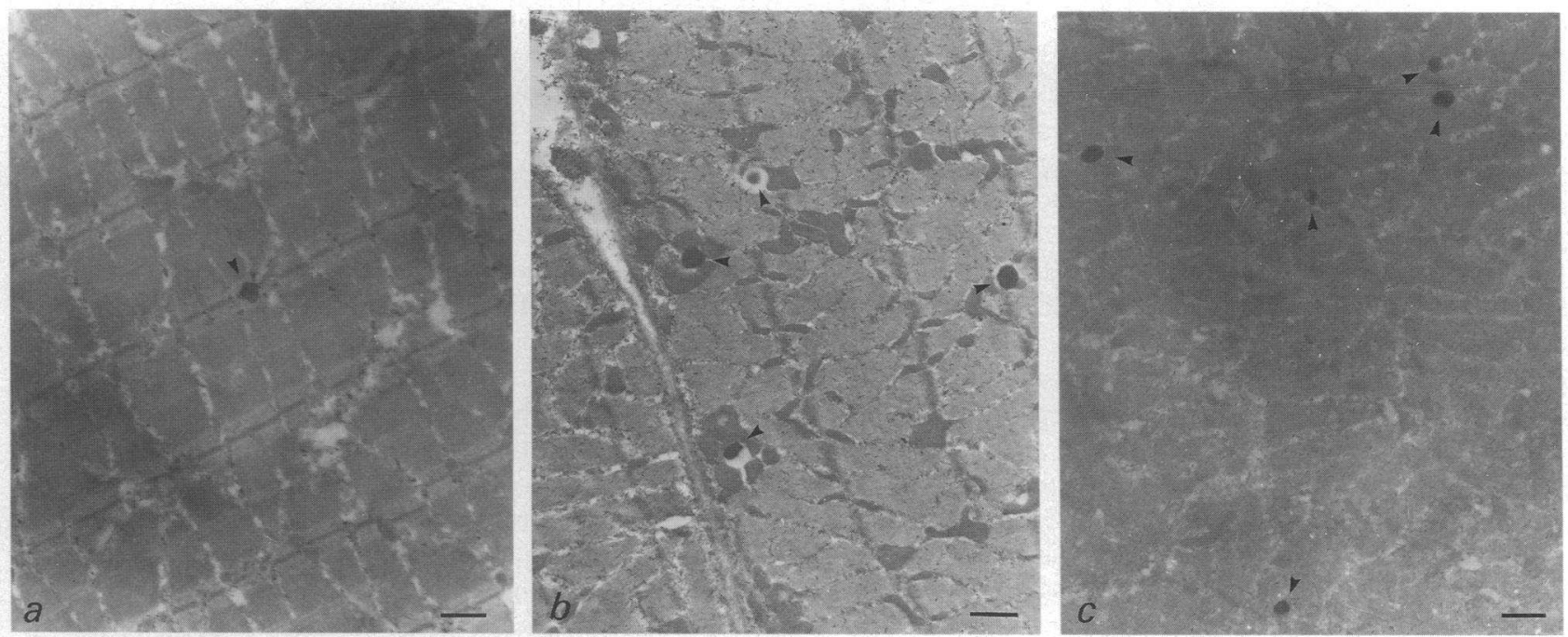

Figure 6. Peroxisome-specific staining in skeletal muscle specimens. Electron microscopy of skeletal muscle specimens after cytochemical staining for catalase activity using diaminobenzidine. Displayed pictures represent noncontrasted sections. In only a few microscopic fields a single peroxisome (arrows) was visualized in control animals $(a)$. In MCK-M $(b)$ animals and MCK-H $(c)$ animals between four and six peroxisomes were observed in each microscopic field. Bar represents $1 \mu \mathrm{m}$. 
of these proteins remains incomplete and a detailed understanding of FFA transport through the plasma membrane has not been achieved. Our study suggests that FFA transport through the endothelial cell layer and the sarcolemmic membrane does not represent an important regulatory step because LPL-driven FFA uptake can increase intracellular FFA levels to the extent that severe myopathy and premature death results. The increase of intracellular FFA levels without an increase in plasma levels suggests that triglyceride hydrolysis and FFA uptake are tightly coupled in muscle. Consequently, the increased formation of FFA albumin complexes and their transport to the liver does not occur. Our results indicate that LPL represents the ratelimiting step in the cellular uptake of triglyceride-derived FFA fulfilling a "gate keeping function" in muscle tissue.

The increased flux of FFA into skeletal muscle tissue through LPL overexpression had a pronounced effect on body weight and body composition in transgenic animals. The animals suffered from retarded growth and weight loss due to the loss of muscle mass as well as adipose tissue mass. We presume that the excessive supply of FFA in muscle tissue caused a muscle disorder which led to the premature death of the animals. The average life span was strictly correlated with the level of LPL overexpression in muscle tissue. Morphological examinations (summarized in Table III) revealed that the transgenic animals suffered from a condition similar to certain myopathies observed in humans. All other organs besides muscle were unaffected. The early stage of the myopathy was mainly characterized by increased numbers of mitochondria and peroxisomes. In many respects this condition resembles human mitochondriopathy in its morphological appearance (33). After prolonged periods of time or when high levels of LPL were expressed in muscle tissue, mitochondriopathy developed into myopathy with severe degeneration of muscle fibers and large deposits of glycogen. Fiber degeneration and the appearance of large numbers of macrophages as a sign of progressive myopathy were accompanied by chronic inflammatory infiltration of the endomysium. Morphologically these phenomena closely resemble progressive or dystrophic human myopathies $(24,25)$. Long chains of centralized nuclei within a high percentage of muscle fibers in this myopathy mimicks the human centronuclear (myotubular) myopathy (34-36). However, nuclei in a centralized position are somewhat nonspecific and are found in several myopathies including neurogenic muscle disease $(24,25)$. Glycogen storage in the sarcoplasma of the animals is most likely caused by the mitochondriopathy with secondary glycogen storage as is also observed in humans (24). Excessive glycogen storage, as found in transgenic mice with the highest levels of LPL expression, is observed in patients with different forms of glycogen storage disease. These patients can develop cardiomyopathy as well as severe myopathy of the respiratory system leading to death from cardio-respiratory insufficiency (25). We assume that the increased uptake of FFA caused by overexpression of LPL in skeletal and cardiac muscle leads to a similar pathological picture and eventually results in the death of these animals. Cardiac failure as the primary cause of death is unlikely because cardiac weight was found to be unchanged. Therefore, respiratory insufficiency appears to be the most likely cause of death in MCK animals.

The constellation of myopathic changes observed in transgenic mice provokes the speculation that disturbed regulation of extracellular lipolysis or increased uptake of FFA might also be causally involved in the pathogenesis of human myopa- thies. The molecular defects of many established human myopathies are unknown. However, several metabolic defects have been characterized that affect FFA catabolism and cause the development of myopathies and mitochondriopathies. These include the deficiencies of carnitine, carnitine palmitoyl transferase I and II, and short, medium, and long chain acyl CoA dehydrogenases. Additionally, disturbances of carbohydrate metabolism and defects in oxidative phosphorylation are associated with the development of certain myopathies. None of these defects completely match the pathology of lipolysis-induced myopathy as observed in MCK mice. For example, defects in FFA transport through the mitochondrial membrane and $\beta$ oxidation are generally causing the accumulation of neutral lipid droplets (37), which is not observed in MCK mouse lines. Disturbances in muscular carbohydrate metabolism such as deficiencies in acid maltase, debranching enzyme, or phosphorylase cause glycogen storage, similarly to that which is observed in LPL transgenic mice, but effects on the number of mitochondria and peroxisomes have not been observed. Therefore, excessive uptake of FFA through the muscle-specific overexpression of LPL might represent a novel pathogenetic mechanism for myopathy.

Overexpression of LPL and an excess supply of FFA caused a large increase in the number of peroxisomes and the activity of the peroxisomal marker enzyme catalase in the skeletal muscle. This is in accordance with earlier observations that FFA can cause peroxisome proliferation in rodents, although most studies were limited to observations in the rodent liver and cultivated liver cells $(38,39)$. Saturated, unsaturated, and polyunsaturated FFA can activate the peroxisome proliferator-activated receptor (PPAR) by interacting with a PPAR retinoid X receptor dimer and thereby induce peroxisome proliferation (40-42). Preliminary results with skeletal muscle tissue from MCK-M animals exhibited an induction of the PPAR-activated gene of acyl CoA oxidase on the mRNA and protein levels compared to controls (manuscript in preparation). This might indicate the involvement of PPAR in the biogenesis of peroxisomes in the transgenic mouse model.

The extent of peroxisomal induction in the skeletal muscle of transgenic mice is remarkable and larger than in any other experimental system studied so far. Our results support the view that FFA as such can act as peroxisome proliferators in vivo. Interestingly, the induction of peroxisome proliferation is an early event as it is seen in mice with the lowest level of LPL expression (MCK-L) at a time when no other morphological changes are detectable. This suggests that peroxisome proliferation preceeds mitochondrial proliferation and might represent a first response of muscle cells to the increased supply of FFA. Indirect evidence that peroxisome proliferation might occur in connection with myopathy is provided by studies in rats and humans treated with clofibrate $(43-45)$. This hypolipidemic drug, a well-established hepatic peroxisome proliferator, can induce myopathy. Unfortunately, to our knowledge, no studies have directly addressed the question of whether fibrates can induce peroxisome proliferation in muscle.

The observation of the induction of the biosynthesis of mitochondria in LPL transgenic mice is interesting, because it is the first direct in vivo observation of a role of FFA in the formation of these cell organelles. At this point we do not know if the newly formed mitochondria are structurally intact and metabolically functional. Morphologically, however, they appear normal. It is tempting to speculate that the induction of proliferation 
of mitochondria by FFA follows a similar mechanism as for peroxisomes, possibly also involving nuclear receptors. At this point it is not known if the induction of peroxisomal and mitochondrial proliferation is a general intracellular effect of FFA or of a certain species of FFA. A suggestion that specifically unsaturated FFA might play a special role in the proliferation of mitochondria comes from observations in yeast, showing that KD115, an unsaturated FFA auxotroph of Saccharomyces cerevisiae, developed structural and functional defects in mitochondria in the absence of unsaturated FFA (46). Additionally it was demonstrated that the OLE1 gene in yeast encoding a fatty acid desaturase, is essential for the movement and the inheritance of mitochondria (47). Our experiments support the concept that FFA represent signal-transducing molecules (4850) and suggest an important role for FFA in the biogenesis of mitochondria in mammals.

Transgenic animals overexpressing human LPL have been generated and characterized in several previous studies (5153). Our results are in agreement with the effect of LPL overexpression on plasma triglyceride levels. However, the observed dramatic effects on body weight, body composition, muscle morphology, and metabolism have not been reported in the previous studies. This could be explained by the different sites and levels of LPL expression in the different transgenic mouse models. In contrast to our approach of tissue-specific LPL overexpression, all other studies used tissue nonspecific expression systems. Under these conditions relatively low levels of LPL expression were detected in many tissues of the body. Therefore, the partitioning of FFA among essentially all tissues in the body and the low level of muscle lipolysis may have precluded seeing the myopathic effects observed in our study. In one report (53), a high perinatal mortality was reported presumably caused by the tissue nonspecific overexpression of the LPL gene under the control of a metallothionein promoter. These observations were not made in our system of muscle-specific LPL overexpression.

In conclusion our results indicate that LPL represents the rate-limiting step for the cellular uptake of triglyceride-derived FFA. FFA transport through the endothelial cell layer and the sarcolemmic membrane apparently does not have such a regulatory function. Excessive FFA uptake in muscle by increased LPL activity can cause major pathologic changes including the proliferation of mitochondria and peroxisomes and the development of a lipolysis-induced myopathy.

\section{Acknowledgements}

The authors want to thank Dr. S. D. Hauschka for the mouse creatine kinase promoter plasmid, Dr. N. S. Shachter for LPL genomic DNA clones, Dr. J. D. Brunzell for the 5D2 antibody, K. Economides, D. Riegelnegg, and R. Teufel for technical assistance, A. Strudel for histologic preparations, I. Salmhofer-Rainer and A. Fuchsbichler for electronmicroscopy, and I. Georgiev and H. Grillhofer for photographic work. We are also grateful to Dr. E. Zechner for the critical review of the manuscript.

This work was supported by the grants P9042 and S7110 (R. Zechner) and P8586 (G. Hoefler) from the Austrian FWF.

\section{References}

1. Nilsson-Ehle, P., A. S. Garfinkel, and M. Schotz. 1980. Lipolytic enzymes and plasma lipoprotein metabolism. Annu. Rev. Biochem. 49:667-693.

2. Olivecrona, T., and G. Bengtsson-Olivecrona. 1987. Lipoprotein lipase in milk: a model enzyme in lipoprotein lipase research. In Lipoprotein Lipase. J. Borensztajn, editor. Evener, Chicago. 15-25.

3. Sparkes, R. S., S. Zollman, I. Klisak, T. G. Kirchgessner, M. C. Komaromy, T. Mohandas, M. C. Schotz, and A. J. Lusis. 1987. Human genes involved in lipolysis of plasma lipoproteins: mapping of loci for lipoprotein lipase to 8p22 and hepatic lipase to 15q21. Genomics. 1:138-144.

4. Brunzell, J. D. 1989. Familial lipoprotein lipase deficiency and other causes of the chylomicronemia syndrome. In The Metabolic Basis of Inherited Disease. R. S. Scriver, A. L. Beaudet, W. S. Sly, and D. Valli, editors. McGraw-Hill Inc., New York. 1165-1180.

5. Lalouel, J.-M., D. E. Wilson, and P.-H. Iverius. 1992. Lipoprotein lipase and hepatic triglyceride lipase: molecular and genetic aspects. Curr. Opin. Lipid. 3:86-95.

6. Santamarina-Fojo, S. 1992. Genetic dyslipoproteinemias, role of lipoprotein lipase and apolipoprotein CII. Curr. Opin. Lipid. 3:186-195.

7. Cryer, A. 1987. Comparative biochemistry and physiology of lipoprotein lipase. In Lipoprotein Lipase. J. Borensztajn, editor. Evener Publishers, Chicago. 227-327.

8. Greenwood, M. R. C., M. P. Cleary, L. Steingrimsdottir, and J. R. Vassell 1981. Adipose tissue metabolism and genetic obesity: the LPL hypothesis. Recent Adv. Obes. Res. 3:75-79.

9. Ausubel, F. M., R. Brent, R. E. Kingston, D. D. Moore, J. G. Seidman, J. A. Smith, and K. Struhl. 1987. Current Protocols in Molecular Biology. Greene \& Wiley-Interscience, New York.

10. Wion, K. L., T. G. Kirchgessner, A. J. Lusis, M. C. Schotz, and R. M. Lawn. 1987. Human lipoprotein lipase complementary DNA sequence. Science (Wash. DC). 235:1638-1641.

11. Johnson, J. E., B. J. Wold, and S. D. Hauschka. 1989. Muscle creatine kinase sequence elements regulating skeletal and cardiac muscle expression in transgenic mice. Mol. Cell. Biol. 9:3393-3399.

12. Walsh, A., Y. Ito, and J. L. Breslow. 1989. High levels of human apolipoprotein A-I in transgenic mice result in increased plasma levels of small high density lipoproteins (HDL) particles comparable to human HDL-3. J. Biol. Chem. 264:6488-6493.

13. Zechner, R., T. C. Newman, B. Sherry, A. Cerami, and J. L. Breslow. 1988. Recombinant human cachectin/tumor necrosis factor but not interleukin-1 downregulates lipoprotein lipase gene expression at the transcriptional level in mouse 3T3-L1 adipocytes. Mol. Cell. Biol. 8:2394-240.

14. Zechner, R. 1990. Rapid and simple isolation procedure for lipoprotein lipase from human milk. Biochim. Biophys. Acta. 1044:20-25.

15. Babirak, S. P., P. H. Iverius, W. Y. Fujimoto, and J. D. Brunzell. 1989. Detection and characterization of the heterozygote state for lipoprotein lipase deficiency. Arteriosclerosis. 9:326-334.

16. Folch, J., M. Lees, and G. H. Sloane-Stanley. 1957. A simple method for the isolation and purification of total lipids from animal tissues. J. Biol. Chem. 226:497-509.

17. Hallaq, Y., T. C. Becker, C. S. Manno, and M. Laposata. 1993. Use of acetyl chloride/methanol for assumed selective methylation of plasma non-esterified fatty acids results in significant methylation of esterified fatty acids. Lipids. 28:355-360

18. Sattler, W., H. Puhl, M. Hayn, G. M. Kostner, and H. Esterbauer. 1991. Determination of fatty acids in the main lipoprotein classes by capillary gas chromatography: $\mathrm{BF}_{3} /$ methanol transesterification of lyophilized samples instead of Folch extraction gives higher yields. Anal. Biochem. 198:184-190.

19. Roels, F., V. Verdonck, M. Pauwels, L. DeCatte, W. Lissens, I. Liebaers, and M. Elleder. 1987. Light microscopic visualization of peroxisomes and plasmalogens in first trimester chorionic villi. Prenatal Diagn. 7:525-530.

20. Peters, T. J., M. Muller, and C. de Duve. 1972. Lysosomes of the arterial wall. I. Isolation and subcellular fractionation of cells from normal rabbit aorta. J. Exp. Med. 136:1117-1127.

21. Pennington, R. J. 1961. Biochemistry of dystrophic muscle: mitochondrial succinate-tetrazolium reductase and adenosine triphosphatase. Biochem. J. 80:649-654.

22. Choi, T., M. Huang, C. Gorman, and R. Jänisch. 1991. A generic intron increases gene expression in transgenic mice. Mol. Cell. Biol. 11:3070-3074.

23. Filipek, P. A., D. N. Kennedy, V. S. Caviness, S. L. Rossnick, T. A. Spraggins, and P. M. Starewicz. 1989. Magnetic resonance imaging-based brain morphometry: development and application to normal subjects. Ann. Neurol. 25:61-67.

24. Schröder, J. M. 1982. Pathologie der Muskulatur. Spezielle Pathologische Anatomie, vol 15 Springer, Heidelberg, New York. 813 pp.

25. Weller, R. O. Colour Atlas of Neuropathology. Oxford Colour Atlases of Pathology, vol 2. Harvey Miller Publishers, Oxford University Press, London. 207 pp.

26. Wetzel, M. G., and R. O. Scow. 1984. Lipolysis and fatty acid transport in the rat heart: electron microscopic study. Am. J. Physiol. 246:C467-C485.

27. Abumrad, N. A., C. C. Forest, D. M. Regen, and S. Sanders. 1991 Increase in membrane uptake of long chain fatty acids early during adipocyte differentiation. Proc. Natl. Acad. Sci. USA. 88:6008-6012.

28. Vyska, K., H. J. Machulla, W. Stremmel, D. Faßbender, W. H. Knapp, 
G. Notohamiprodjo, U. Gleichmann, H. Meyer, E. J. Knust, and R. Körfer. 1988. Regional myocardial free fatty acid extraction in normal and ischaemic myocardium. Circulation. 78:1218-1223.

29. Stremmel, W., G. Strohmeyer, F. Borchard, S. Kochwa, and P. D. Berk. 1985. Isolation and partial characterization of a fatty acid binding protein in rat liver plasma membranes. Proc. Natl. Acad. Sci. USA. 82:4-8.

30. Trigatti, B. L., D. Mangroo, and G. E. Gerber. 1991. Photoaffinity labeling and fatty acid permeation in 3T3-L1 adipocytes. J. Biol. Chem. 266:2262122625 .

31. Abumrad, N. A., M. Raafat El-Maghrabi, E.-Z. Amri, E. Lopez, and P. A. Grimaldi. 1993. Cloning of a rat adipocyte membrane protein implicated in binding or transport of long-chain fatty acids that is induced during preadipocyte differentiation. J. Biol. Chem. 268:17665-17668.

32. Schaffer, J. E., and H. F. Lodish. 1994. Expression cloning and characterization of a novel adipocyte long chain fatty acid transport protein. Cell. 79:427436.

33. Walter, G. F. 1983. Myoencephalopathies with abnormal mitochondria: a review. Clin. Neuropathol. 2:101-113.

34. Engel, W. K., G. N. Gold, and G. Karpati. 1968. Type 1 fiber hypertrophy and central nuclei. A rare congenital muscle abnormality with a possible experimental model. Arch. Neurol. 18:435-444.

35. Spiro, A. J., G. M. Shy, and N. K. Gonatas. 1966. Myotubular myopathy. Persistence of fetal muscle in an adolescent boy. Arch. Neurol. 14:1-14.

36. Sher, J. H., A. B. Rimalowski, T. J. Athanassiades, and S. M. Aronson. 1967. Familial centronuclear inyopathy: a clinical and pathological study. Neurology. 17:727-742.

37. Cumming, W. J. K., J. J. Fulthorpe, P. Hudgson, and M. Mahon. 1994. In Color Atlas of Muscle Pathology. Mosby-Wolfe Publishers, London. 202 pp.

38. Issemann, I., R. A. Prince, J. D. Tugwood, and S. Green. 1993. The peroxisome proliferator-activated receptor:retinoid $\times$ receptor heterodimer is activated by fatty acids and fibrate hypolipidaemic drugs. J. Mol. Endocrinol. 11:3747.

39. Banner, C. D., M. Göttlicher, E. Widmark, J. Sjörvall, J. J. Rafter, and J. A. Gustafsson. 1993. A systematic analytical chemistry/cell assay approach to isolate activators of orphan nuclear receptors from biological extracts: characterization of the peroxisome proliferator activated receptor activators in plasma. $J$. Lipid Res. 34:1583-1591.

40. Issemann, I., and S. Green. 1990. Activation of a member of the steroid hormone receptor superfamily by peroxisome proliferators. Nature (Lond.). 347:645-650.

41. Göttlicher, M., E. Widmark Q. Li, and J. A. Gustafsson. 1992. Fatty acids activate a chimera of the clofibric acid-activated receptor and the glucocorticoid receptor. Proc. Natl. Acad. Sci. USA. 89:4653-4657.

42. Keller, H., C. Dreyer, J. Medin, A. Mahfoudi, K. Ozato, and W. Wahli. 1993. Peroxisome proliferator-activated receptors and lipid metabolism. Proc. Natl. Acad. Sci. USA. 90:2160-2164.

43. Teräväinen, H., A. Larsen, and M. Hillborn. 1977. Clofibrate-induced myopathy in the rat. Acta Neuropathol. 39:135-138.

44. Langer, T., and R. L. Levy. 1968. Acute muscular syndrome associated with administration of clofibrate. N. Engl. J. Med. 279:856-858.

45. Katzilambros, N., J. Braaten, B. D. Ferguson, and A. F. Bradley. 1972 Muscular syndrome after clofibrate. N. Engl. J. Med. 282:1110.

46. Tung, B. S., E. R. Unger, B. Levin, T. A. Brasitus, and G. S. Getz. 1991 Use of an unsaturated fatty acid auxotroph of Saccharomyces cerevisiae to modify the lipid composition and function of mitochondrial membranes. J. Lipid Res. 32:1025-1031.

47. Stewart, L., and M. P. Yaffe. 1991. A role of unsaturated fatty acids in mitochondrial movement and inheritance. J. Cell Biol. 115:1249-1257.

48. Distel, R. J., G. S. Robinson, and B. M. Spiegelman. 1992. Fatty acid regulation of gene expression: transcriptional and post-transcriptional mechanisms. J. Biol. Chem. 267:5937-5941.

49. Grimaldi, P., S. M. Knoble, R. R. Whitesell, and N. A. Abumrad. 1992. Induction of aP2 gene expression by non-metabolized long-chain fatty acids. Proc. Natl. Acad. Sci. USA. 89:10930-10934.

50. Amri, E. Z., G. Ailhaud, and P. A. Grimaldi. 1994. Fatty acids as signal transducing molecules: involvement in the differentiation of preadipose to adipose cells. J. Lipid Res. 35:930-937.

51. Shimada, M., H. Shimano, T. Gotoda, K. Yamamoto, M. Kawamura, T. Inaba, Y. Yazaki, and N. Yamada. 1993. Overexpression of human lipoprotein lipase in transgenic mice: resistance to diet induced hypertriglyceridemia and hypercholesterolemia. J. Biol. Chem. 268:17924-17929.

52. Liu, M. S., F. R. Jirik, R. C. LeBoeuf, H. Henderson, L. W. Castellani, A. J. Lusis, Y. Ma, I. J. Forsythe, H. Zhang, E. Kirk, et al. 1994. Alteration of lipid profiles in plasma of transgenic mice expressing human lipoprotein lipase. J. Biol. Chem. 269:11417-11424.

53. Zsigmond, E., E. Scheffler, T. M. Forte, R. Potenz, W. Wu, and L. Chan. 1994. Transgenic mice expressing human lipoprotein lipase driven by the metallothionein promoter. J. Biol. Chem. 269:18757-18766. 